\begin{tabular}{llll} 
ZAPISKI HISTORYCZNE & Zeszyt 2 \\
\hline
\end{tabular}

http://dx.doi.org/10.15762/ZH.2016.64

GRZEGORZ BIAŁUŃSKI

(University of Warmia and Mazury in Olsztyn)

\title{
LAWLESS OR STILL LAWFUL? \\ ABOUT WERGILD (MAN-PRICE) AND VENDETTA IN THE DUCHY OF PRUSSIA AND ROYAL PRUSSIA IN THE EARLY MODERN TIMES*
}

Key words: early modern criminal law; Chełmno law; the General State Laws for the Prussian States; judicial system of Early Modern Warmia (Ermland); bloody retaliation

In literature the subject matter appearing in the title of the article was not particularly popular among scholars. Apart from the work by Georg Adalbert von Mülverstedt ${ }^{1}$ and recently by Grzegorz Białuński ${ }^{2}$ it appears on the margin of scientific deliberations. ${ }^{3}$ The vendetta and wergild were still applied in the early modern times, but they disappeared in the second half of the $17^{\text {th }}$ century. According to the findings of G. A. von Mülverstedt, the institution of wergild died out after 1650, in the times of the rule of Frederick William, Elector of Brandenburg (who died in 1688). The institution of vendetta was abolished by law owing to the Torun revision of the Chełmno law (1594) and the General State Laws for the Prussian States (1620). It was not until then that homicide became a public offence prosecuted ex officio. Undoubtedly, the condition of the research justifies the need to study the issue more thoroughly.

The source base for the article constitute mostly the digests of laws from the Prussian territory. The first of them is the collection of laws of 1512 commenting on

* This article is an English version of the article which appeared in "Zapiski Historyczne", vol. 81, 2016. Translation was part of the task "The publication of 'Zapiski Historyczne' in the English language version, Vol. 81, 2016, books (zeszyt 1-4)" financed as part of the agreement 698/P-DUN/2016 with the resources of the Ministry of Science and Higher Education devoted to the popularization of science.

${ }^{1}$ Georg Adalbert von Mülverstedt, Beiträge zur Geschichte des Wergeldes in Preussen, Der neuen Preußischen Provinzial-Blätter andere Folge, Bd. 3: 1853, pp. 373-382, 390-413; Bd. 4: 1853, pp. 292, 420 .

${ }^{2}$ Grzegorz BiaŁuński, Zemsta matka sprawiedliwości. Wergeld (główszczyzna) w Prusach Krzyżackich i Prus Książęcych, Czasopismo Prawno-Historyczne, vol. 67: 2015, no. 2, pp. 11-29, here the analysis of the literature of the subject matter.

${ }^{3}$ Comp. Georg Matern, Um Hals und Hand. Beiträge zur Geschichte der Rechtspflege im Ermland, Braunsberg 1912, pp. 33-35; Danuta JANICKA, Prawo karne $w$ trzech rewizjach prawa chetmińskiego z XVI wieku, Toruń 1992, pp. 90-91, 95-96. 
the Chełmno law titled "Dys nochgeschrebene ist Colmisch recht," which includes 22 articles concerning the damages of the body. ${ }^{4}$ The next one is the collection of judicial sentences issued according to the Chełmno Law referred to as "Gemeine Urtheile" (or "Laufende Urtheile" / "Gemeine Laufende Urtheile"), which was increasingly popular in the courts, printed many times in the years 1553-1600, rewritten (the manuscripts come from the $17^{\text {th }}$ and $18^{\text {th }}$ centuries), and still used by the Prussian courts in the $18^{\text {th }}$ century. ${ }^{5}$ However, the major quantity of the information is provided by the revisions of the Chełmno law of the second half of the $16^{\text {th }}$ century. First was the so called revision of Lidzbark prepared in 1566; it was not approved of by the Prussian estates, the Polish king and the Prussian duke, but became an important source of law in the judicial system of Warmia. It was eventually published in 1711 by Johann Georg Kunigk. ${ }^{6}$ The next one was the so called revision of Nowe Miasto of 1580 ("Ius Culmense Emendatum"), which was not approved of by the dietine, the king and the Prussian duke. Nevertheless, the revision was applied in the judicial practice, mainly in the cities; it was also published many times and translated e.g. into Polish. ${ }^{7}$ It is known that it was used in Warmia, particularly in cases concerning the practical application of the wergild and compensatory damages. ${ }^{8}$ The last one - the so called Torun revision of 1594 was created without the participation of the nobility and representatives of the

${ }^{4}$ Ferdinand Neumann, Ueber das Vorkommen der Talion in der älteren preußischen Rechtspflege, Der neuen Preußischen Provinzial-Blätter ander Folge, Bd. 2: 1852, pp. 174-175; this author did not notice, that the regulations of this statute, unknown before in the Chelmno law, had been taken from the Saxon law, but from its late varieties - from the territory of Meißen [Polish: Miśnia].

${ }^{5}$ Emil Steffenhagen, Deutsche Rechtsquellen in Preussen vom XIII. bis zum XVI. Jahrhundert, Leipzig 1875, pp. 211, 226-230; I use the edition: Die lauffende Urtel so man teglich bei Gerichte braucht, hrsg. v. Albert Polman, Königsberg 1577.

${ }^{6}$ Ius Culmense correctum una cum procesu iuris pro dioecesi Varmiensi, Brunsbergae 1711; in the work I use the Polish translation: Rewizja lidzbarska prawa chetmińskiego 1566 (1711), trans. by Andrzej Groth, Koszalin 1997. About the revision see Alojzy Szorc, Dominium warmińskie 12431772. Przywilej i prawo chetmińskie na tle ustroju Warmii, Olsztyn 1990, pp. 343-362.

${ }^{7}$ Comp. Janusz SondeL, Wstęp historyczny do przekładu rewizji nowomiejskiej, [in:] Rewizja nowomiejska prawa chetmińskiego 1580 (1814) zwana także Jus Culmense emendatum lub Jus Culmense Polonicum, trans. by Irena Malinowska-Kwiatkowska, Janusz Sondel, verified by Zygfryd RymaSZEWSKI, Toruń 1993, pp. 9-44. In this work I use this translation.

${ }^{8}$ The evidence for this are separate copies of the $17^{\text {th }}-18^{\text {th }}$ century fragments of this revision kept in the archdiocesal archive of Ermland [Warmia]; the most important of them is "Vom wehrgelde, gewette und busse" (Archiwum Archidiecezji Warmińskiej w Olsztynie [Archive of the Archdiocese of Warmia in Olsztyn] (further cit. AAWO), AB, H 32a, fol. 66-68), which includes the following articles of the Nowe Miasto revision: book II, art. XXXVII.19; book V, art. CCXCI.25-CCCVI.40. Moreover, the fragment titled "Bericht von wehrgelde, gewette und busse" (AAWO, AB, C 13, fol. 350-354), which includes the same articles; the chronology of the parts of the body was changed and some parts were omitted. Another extract concerning the compensation damages for injuries: "Von Wundenn insonderheit" (AAWO, AB, H 60, fol. 91-93), includes almost identical regulations as the first from the above mentioned fragments, with one modification - probably erraneous double entry concerning the compensation damages for the neck, where in fact one of them referred to the back. I would like to thank Rev. Prof. Andrzej Kopiczko for making those materials available to me. 
Duchy of Prussia. The project was not even debated on during the dietine, but it was accepted by Gdańsk and adjacent cities (which explains the origin of its future name "Danziger Kulm"). ${ }^{9}$ The revision was not published until the $18^{\text {th }}$ century by Michał Krzysztof Hanow. ${ }^{10}$ The final legal digest were the General State Laws for the Prussian States of 1620, which, unlike the above mentioned digests, was officially approved of and printed. ${ }^{11}$ The corrected General State Laws for the Prussian States was again approved of in $1685 .{ }^{12}$

Let us remind that the Teutonic Order introduced the wergild in Prussia in a form of payment (man-price) for manslaughter or homicide; originally, it could be exchanged for vendetta. The wergild was common and concerned all the free classes of society. The size of the wergild depended on the social rank of the victim. Four basic fees were applied: 8, 16, 30 and 60 grzywnas. The wergild was paid to the next of kin in both the paternal and maternal lines. With time Prussian rulers acquired the right to receive part of the wergild (the Teutonic Order, bishops, the chapter). Apart from the financial payment what was required was the act of submission - the rite of the honorary punishment. ${ }^{13}$

As has been mentioned above, the wergild was used for a very long time. In 1436 the Prussian estates, when asked by the Grand Master whether to maintain the man-price or look for another form of punishment for homicide, opted for the wergild. ${ }^{14}$ The situation remained unchanged until the times of the duchy in Prussia. Duke Albrecht $(1525-1568)^{15}$ granted the privileges of the wergild, most of which constituted the renewal of former privileges. However, the fact of repeating the wergild formula indicates that it continued to be used in practice. For example, free men of Orło in the starosty of Ryn in the renewed privilege of 1538 received the confirmation of the wergild in the amount of 30 grzywnas. ${ }^{16}$ Ten years earlier the wergild was confirmed in the Prussian law in Sambia to Nikolaus von Sirgitten and Johann Koglande. ${ }^{17}$

${ }^{9}$ Zbigniew ZDRójкоwsкi, Zarys dziejów prawa chetmińskiego 1233-1862. Studium z okazji siedemsetpięćdziesięciolecia wydania przywileju chetmińskiego oraz lokacji miast Chetmna i Torunia, Toruń 1983 , p. 49.

${ }^{10}$ Ius Culmense ex ultima revisione, Danzig 1745.

${ }^{11}$ Comp. Stanisław Salmonowicz, Kodyfikacje wschodniopruskie. Próba ogólnego zarysu, [in:] idem, Od Prus Książęcych do Królestwa Pruskiego. Studia z dziejów prusko-pomorskich, Olsztyn 1992, pp. 24-30.

${ }^{12}$ Churfürstlich Brandenburgisches revidirtes Landrecht des Herzogthumbs Preussen, Königsberg 1685.

${ }^{13}$ G. BIAŁUŃsKi, op. cit., passim.

${ }^{14}$ Acten der Ständetage Preussens unter der Herrschaft des Deutschen Ordens, hrsg. v. Max ToEPPEN, Bd. 2, Leipzig 1880, p. 9. The old law was supported by the knighthood, while the authorities of the town asked for some time to think it over. No information that the towns objected to it. The case continued to be debated on. Comp. ibid., p. 579 (1443 r.), but nothing has changed.

${ }^{15}$ G. A. von MüLVERstedt, op. cit., p. 395.

${ }^{16}$ Geheimes Staatsarchiv Preussischer Kulturbesitz, Berlin-Dahlem, XX. Hauptabteilung, Ostpreussische Folianten, Nr. 332, fol. 10-11.

${ }^{17}$ G. A. von Mülverstedt, op. cit., p. 395. 
At the beginning of the Early Modern period the wergild was mentioned in the collection of laws of 1512 titled "Dys nochgeschrebene ist Colmisch recht." ${ }^{18}$ In art. 9 it read that if somebody perpetrated a crime in self-defence ("notwere") or by accident ("ungeschicht"), they had the right to pay the compensation in a form of the wergild. However, if the crime was committed deliberately ("frebelich"), they should be punished according to the law of talion ("a hand for a hand," "a neck for a neck," "an eye for an eye," "a tooth for a tooth"). ${ }^{19}$ Applying the rules of talion constituted a progress as it excluded the use of collective responsibility. The only person exempt from paying the wergild was the guarantor of the accused if the crime had been committed in self-defence or by accident. Moreover, art. 3 of the collection of laws stated that the punishment for cutting a finger was a quarter of the wergild ("mit der helffte eines halben"). Art. 20 of the commentary stipulated that cutting three fingers (or fewer or more) with one stroke constituted one damage. ${ }^{20}$ The damage was estimated to be worth 36 shillings (we do not know according to which value of the wergild); later such a crime entailed the payment of one-tenth of the "rightful compensation." 21

The digest with some amendments and supplements was included in the code called "Gemeine Urtheile."22 It included the record about 36 shillings for cutting a few fingers with one blow; the compensation damages for harming or cutting one finger amounted to 36 shillings as well. More serious injuries ( the longest naildeep and the longest finger-deep) required the payment of the half of the wergild. ${ }^{23}$ The whole wergild amounted to 12 grzywnas payable to the plaintiff, without any extra payment to the ruler. Homicides and injuries could not be left unpunished. The law of talion was abolished, and the wergild was to apply only in civil cases; still, the wergild was applied in criminal cases if such was the decision of the court (undoubtedly after the settlement had been concluded between the parties). ${ }^{24} \mathrm{Hav}$ ing eliminated collective responsibility, the next advancement was the abolition of the use of the wergild outside the court.

${ }^{18}$ F. Neumann, op. cit., pp. 174-175; E. Steffenhagen, op. cit., p. 210, underlined that the regulation about the wergild discussed below had been known in this form in Prussia in the $15^{\text {th }}$ century.

${ }^{19}$ As G. Matern (op. cit., p. 35) rightly pointed out such records are to be found in some privileges for Prussians in the $13^{\text {th }}$ century $(1261,1284)$.

${ }^{20}$ The reverse should be applied - if the fingers were cut off independently, it required compensation for each finger separately, comp. Rewizja nowomiejska, book V, art. CCCIV.38, p. 144

${ }^{21}$ Rewizja nowomiejska, book V, art. CCCIV.38, p. 144; F. Neumann, op. cit., p. 174, concluded that no more than 36 shillings could be paid; he counted himself that it constituted one-tenth of the whole wergild (at that time 6 grzywnas). Probably it referred to some extra compensation resulting from the fact of cutting off the finger (see art. 3); assuming that the whole wergild amounted to 24 grzywnas according to the revisions of the Chełmno law, we receive 6 grzywnas and one-tenth of it, which are 36 shillings.

${ }^{22}$ E. Steffenhagen, op. cit., pp. 211, 226-230.

${ }^{23}$ It was maintained by the subsequent revisions of the Chełmno law, comp. Rewizja nowomiejska, book V, art. CCLXXX.14, p. 138.

${ }^{24}$ Die lauffende Urtel, pp. 19-21, 23. 
The wergild for homicide also appeared in the revisions of the Chelmno law of the second half of the $16^{\text {th }}$ century (the revision of Lidzbark of 1566 and the revision of Nowe Miasto of 1580). ${ }^{25}$ Yet, the latter revision stipulated that the general rule was that the punishment for homicide was death. ${ }^{26}$ The Lidzbark revision provided that it was always possible to avoid the death penalty by effectuating the payment of a certain amount of money ("one may avoid the death penalty according to the law"). ${ }^{27}$ The revision of Nowe Miasto allowed it only in case of unintentional or accidental killing ("if somebody kills another person not deliberately, but by accident or by carelessness"), when the assassinator was accused by the "city's practice" if there was not enough evidence for their guilt, ${ }^{28}$ or in cases when "law appeased the punishment." ${ }^{29}$ The last case concerned minor offenders, who were exempt from capital punishment ("minors do not commit any crimes that were punished with capital punishment"); the wergild in this case was paid by the legal guardian of the minor - it was deducted from the wealth of the minor and its value depended on the social class of the victim of the homicide or injury. ${ }^{30}$ In the latest Torun revision of 1594 the wergild was limited only to the cases of unintentional or accidental killing (the "compensation damage"). ${ }^{31}$ All the revisions for accidental killers e.g. those who had committed the crime of an injury during hunting away from the public road, during cutting trees, unloading a cart etc. did not involve the death penalty provided the perpetrator shouted with a warning. ${ }^{32}$ Yet, the circumstances did not exempt the killer from paying the man-price. ${ }^{33} \mathrm{~A}$ similar situation occurred when death was caused by an animal belonging to someone. ${ }^{34}$ The man-price was not required only when the crime took place in self-defence or

${ }^{25}$ This is what representatives of small towns demanded during the discussion over the draft of the revision, comp. their demands of 1556: AAWO, AB, C 16, fol. 23-26; A. SzorC, op. cit., p. 442. They asked for the rates of the whole wergild, half the wergild, compensation damages and "mulkta" for the judge to be specified in the draft.

${ }^{26}$ D. JANICKA, op. cit., p. 96; Rewizja nowomiejska, book II, art. XXXVII.19, pp. 58-59; book V, art. CCLXXX.14, p. 138.

${ }^{27}$ Rewizja lidzbarska, book II. 28, p. 93; III.1, 33, p. 113, 127; D. JANICKA, op. cit., p. 96.

${ }^{28}$ D. JANICKA, op. cit., p. 96.

${ }^{29}$ Rewizja nowomiejska, book II, art. XXXVII.19, pp. 58-59; book V, art. CCLXXX.14, p. 138.

${ }^{30} \mathrm{Ibid}$., book V, art. CCCXV.49, pp. 146-147.

${ }^{31}$ Ius Culmense ex ultima revisione, V2, 26, pp. 271-272; D. JANICKA, op. cit., pp. 20-21, 55, 95-96.

${ }^{32}$ Ius Culmense ex ultima revisione, V2, 7, 10-12, pp. 241-243; Rewizja nowomiejska, book V, art. CCCXLIV.78-CCCXLVI.80, pp. 154-155; Rewizja lidzbarska, book V.14, 15, 16, pp. 210-211; D. JANICKA, op. cit., p. 96. The articles were taken from Alter Kulm, zob. Das alte Kulmische Recht, mit einem Wörterbuche, hrsg. v. C[hristian] K[arl] Leman, Berlin 1838, book V, XV-XVII, XXV; Prawo starochetmińskie 1584 (1394), ed. Witold MaIseL, Zbigniew ZdrójKowsKi, transl. by Andrzej BzDęGA, Alicja GACA, Torun 1985, book V, art. 15-17, 25.

${ }^{33}$ Rewizja lidzbarska, book V.16, p. 211; Ius Culmense ex ultima revisione, V2, 26, pp. 271-272; Rewizja nowomiejska, book II, art. XXXVII.19, p. 58. In the last two revisions the wergild was mentioned in reference to the injury caused by an accidental blow with a stone or bullet, a falling stone or any other material to be found on the construction site.

${ }^{34}$ Like in: Rewizja lidzbarska, book V, art. 22, p. 213. 
in the case of killing an outlaw. ${ }^{35}$ To sum up, the next step to reduce the wergild was ordering it only in the case of unintentional and accidental killings, and exempting from the man-price if killing occurred in self-defence.

It was also possible to use the man-price to redeem any other private claim the consequence of each would be the punishment "according to the law [...] owing to committing the crime." ${ }^{36}$ However, it must be stressed that in both cases it was not a compensation for the manslaughter, but rather compensation damages (German: Busse). The condition under which it was possible to redeem the public sentence with the wergild was a settlement concluded by both parties upon the permission of the judge; the breach of the settlement entailed criminal liability. Concluding a settlement could take place out of the court during private negotiations in the presence of relatives or due to official settlement proceedings in the presence of the city council or judges. ${ }^{37}$ If there appeared difficulties in concluding the settlement, the judge could make a decision about the manner and conditions of the settlement. Breaching the judge's decision again entailed criminal liability ${ }^{38}$ The regulations of the Torun revision went a step further. It read there that the settlement in criminal cases was not binding for the judge and he could continue to consider the case and issue a sentence. ${ }^{39}$ It should be stressed that also in The General State Laws for the Prussian States of 1620, any settlement in criminal cases was forbidden, except cases concerning injuries. ${ }^{40}$ In civil cases the settlement was permitted and naturally led to the end of a trial. ${ }^{41}$

The total wergild according to all the revisions amounted to 24 grzywnas and was paid within 3 months months (12 weeks), whilst compensation damages were paid within two weeks. Each private sentence was accompanied by a public sentence in the form of a fine [Polish: mulkta; German: Gewette] of 4 grzywnas to the judge. ${ }^{42}$

${ }^{35}$ Ibid., book V, art. 35, 40, pp. 220, 223.

${ }^{36}$ Rewizja nowomiejska, book II, art. XXXVII.19, pp. 58, the wergild was mistaken for the mulkta.

${ }^{37}$ Rewizja lidzbarska, book II.46, p. 104; Rewizja nowomiejska, book II, art. XLV.27-XLVI.28, XCII.74-XCV.77, pp. 61, 75-76; D. JANICKA, op. cit., p. 67-68.

${ }^{38}$ Rewizja lidzbarska, book II.28, p. 93; Rewizja nowomiejska, book II, art. XXXVII.19, p. 59.

${ }^{39}$ D. JANICKA, op. cit., p. 68.

${ }^{40}$ Comp. Wiesław Litewski, Landrecht des Herzogtums Preussen von 1620. I. Strafrecht, Warszawa-Kraków 1982, p. 82.

${ }^{41}$ D. JANICKA, op. cit., p. 68.

${ }^{42}$ Ibid., p. 55. Comp. Rewizja lidzbarska, book II.28, p. 93; Rewizja nowomiejska, book II, art. XXXVII.19, p. 59, it is mentioned here that originally, according to the Chełmno law, it amounted to 30 shillings, which corresponded to 4 grzywnas calculate taking into account that one grosch was equal to 18 denars. Such a monetary system in the Duchy of Prussia and Royal Prussia was introduced after the reform of 1528; then 1 mark was equal to 20 gorsch and 60 shillings / 360 denars, comp. Janusz MaŁŁeK, Ostatnie stadium reformy monetarnej w Prusach Królewskich i Książęcych (1530-1531), [in:] idem, Dwie części Prus. Studia z dziejów Prus Książęcych i Prus Królewskich w XVI i XVII wieku, Toruń 2015 (ed. 2), pp. 149-152. 
In early modern sources there is no information who paid the wergild - the perpetrator only or their relatives - as it had been in the past. ${ }^{43}$ According to the regulations of "Gemeine Urtheile" and the revision of the Chełmno law, it should be assumed that the only payer was the person guilty of the crime. ${ }^{44}$ On the other hand, the sources mention parties of the settlement and the victim's relatives, ${ }^{45}$ which makes us think that there was a broader circle of relatives, who were somehow connected with the act of the wergild. Still, we do not know whether they were obliged to help to pay the money. The recipients of the man-price are not defined, either. According to the regulations in the Chełmno law it should be assumed that the money was paid to the plaintiff (a close relative or the victim themselves) ${ }^{46}$ It seems that the general tendency of the period was to reduce the range of people entitled to collect the wergild to the closest agnate or his heirs according to the degree of kinship. ${ }^{47}$ The liability to pay the money was limited only to the person guilty of the crime. ${ }^{48}$ The settlement of 1638 says that inheritors had to agree to the wergild being paid from the totality of the wealth; at least they had to relinquish this part of the wealth. ${ }^{49}$ The wergild was no longer divided among the family and the supreme authority, which had been the case in the Middle Ages. ${ }^{50}$

Damage to the human or injury required compensation in the financial form. It was not only to compensate for the physical harm, but also for the loss of honour. Each part of the body had its price determined by the function it played in a human body. ${ }^{51}$ As early as the pre-Christian times the legal regulations listed individual parts of the body from head to toe. ${ }^{52}$ It was also the case in the Prussian territories of the early modern period. In "Gemeine Urtheile" the highest price was paid for the head (half the wergild), ears (for cutting off an ear - half the wergild, for injuring it - 30 shillings and 4 shillings to the judge), eyes (half the wergild), a cheek (half the wergild), a nose (half the wergild), teethe (half the wergild; for one tooth -

${ }^{43}$ G. BiaŁuńsKi, op. cit., pp. 22-23.

${ }^{44}$ Rewizja nowomiejska, book II, art. XXXVII.19, pp. 58-59.

${ }^{45}$ Rewizja lidzbarska, book II, art. 28, p. 93; Rewizja nowomiejska, book II, art. XXXVII.19, pp. 58-59.

${ }^{46}$ Comp. Rewizja lidzbarska, book II, art. 28, s. 93; book III, art. 75, p. 147.

${ }^{47}$ This is what a regulation in Rewizja nowomiejska seems to prove, book V, art. CCCIV.48, p. 146; the closest living agnate insisted on paying the compensation (and the wergild). Comp. also Rewizja lidzbarska, book III, art. 25, 37, pp. 123, 129 (here "the biggest friend" - in a sense of a relative).

${ }^{48}$ Rewizja lidzbarska, book III, art. 22, p. 122; the wergild of a fugitive accused of the crime was paid only from his wealth.

${ }^{49}$ [Ludwig] von BACZKо, Beispiel von der noch im Jahre 1638 in Ostpreußen erlassenen Blutrache, und einem Erkenntni $\beta$ auf Wehrgeld aus dem Jahre 1754, Beiträge zur Kunde Preußens, Bd. 6, Königsberg 1824, p. 360.

${ }^{50}$ G. BiaŁuńsKi, op. cit., p. 22.

51 The customs dates back to the Pre-Christian Times, see Przemysław TrszkA, Prawa barbarzyńskie o czynach przeciw ciału i cielesności człowieka (od końca V do początku IX wieku). „Corpus homini" jako kategoria kulturowa, Lublin 2010, pp. 138-139.

${ }^{52}$ Ibid., p. $69 \mathrm{ff}$. 
36 shillings), a chin (half the wergild), a neck (half the wergild), a shoulder (half the wergild), an arm (half the wergild), an elbow (half the wergild), a fist (half the wergild), part of a hand (half the wergild), a finger (36 shillings), a nail (30 shillings). If the same part of the body, for the damage of which compensation had already been paid was harmed for the second time, 30 shillings and a fine to the judge had to paid. ${ }^{53} \mathrm{~A}$ similar list along with the order and the amount of the charges (normally half the wergild) can be found in the Nowe Miasto revision of the Chełmno law: a head, an ear (the charge for an injury did not appear), an eye, a jaw, lips, teeth (for a single tooth - 30 shillings and a fine of 4 shillings to the judge), a chin, neck, trunk, arm, shin, elbow, hand (for a smaller damage one-tenth of the wergild), fingers (for part of a finger one tenth of the wergild), nails (30 shillings). The entry about a part of the body which had been affected for the second time also appeared in this document: the charge amounted to 30 shillings and a fine of 8 shillings paid to the judge. They also added a regulation concerning the fact of cutting off a few parts of the body simultaneously, which should be treated as one damage estimated at one-tenth of the wergild. Parts of the body cut off separately ( fingers, hands, legs, a tooth) entailed a separate "sonderliche Busse" of one-tenth of the wergild. ${ }^{54}$ In the Lidzbark revision the list was not so detailed and did not follow the "head to toe" rule..$^{55}$ Unlike in the Nowe Miasto revision, it was possible to redeem each injury, even the most serious one (by paying the whole or half of the wergild). ${ }^{56} \mathrm{It}$ was not until the Torun revision that the detailed list was omitted and the law concerning the man-price referred to the general punishment for intentional injury. ${ }^{57}$ For example, injuries inflicted on public roads entailed a punishment consisting in cutting off a hand or "eternal" banishment; the perpetrator also had to compensate the victim for the costs of medical treatment. ${ }^{58}$ In The General State Laws for the Prussian States of 1620 no lists of fines are to be found, either. What is included is the obligation to pay compensation for the costs of medical treatment. The wergild is not even mentioned when the sum of the compensation damages is specified. ${ }^{59}$

In the light of the above-mentioned information, it may be noticed that the man-price for a long time constituted a kind of a monetary unit used to define the amount of money to be paid in the way of punishment or compensation damages. In the case of the compensation damages, the amount to paid was deter-

${ }^{53}$ Die lauffende Urtel, pp. 21-23.

${ }^{54}$ Rewizja nowomiejska, book V, art. CCXCI.25-CCCIV.39, pp. 141-144.

${ }^{55}$ First they mentioned teeth, a hand, a head and a nose, and in another place - lips, eyes, tongue, ears, genitalia, hands and legs, see Rewizja lidzbarska, book III.5, 6, 7, 15, pp. 115-116, 119.

${ }^{56}$ Ibid., book III.1, 12, pp. 113, 118. In the Nowe Miasto revision it stipulated that it was obligatory to cut off the hand or to sentence to death, see Rewizja nowomiejska, book II, art. XXXVII.19; book V, art. CCLXXIX.13, CCLXXXII.16, CCXC.24, CCCV.39, pp. 58-59, 138, 140, 144.

${ }^{57}$ D. JANICKA, op. cit., pp. 99.

${ }^{58}$ Ius Culmense ex ultima revisione, V2, 21, 1-3, pp. 267.

${ }^{59}$ W. Litewski, op. cit., pp. 72, 141-142, it was maintained in the revision of the General State Laws for the Prussian States of 1685, see Churfürstlich Brandenburgisches revidirtes Landrecht des Herzogthumbs Preussen, Bd. VI, tit. X, art. I, § I-II, pp. 961-962. 
mined by the kind of crime ("it was smaller or bigger depending whether a crime was considered major or minor"). ${ }^{60}$ As has been mentioned, the sentences usually amounted to half the wergild or were proportionally smaller, e.g. 30, 36 shillings or one-tenth of the whole wergild. Other examples of using the wergild as a kind of conversion rate for the punishment: if the guilty, who was likely to receive the death penalty, escaped from prison before the end of the trial, the responsibility to pay the whole wergild fell on the judge. ${ }^{61}$ The total amount of the wergild was paid by a person who had assisted in a murder, while only half of it was to be paid by a person who had helped the perpetrator to injure the victim. ${ }^{62}$ The amount of the wergild constituted the maximum sum of warranty in criminal cases (excluding financial debts). ${ }^{63}$

The sum of the total wergild in the collection of 1512 remains unknown. According to F. Neumann, it was 6 grzywnas, but the author failed to provide a source of the information. ${ }^{64}$ It was precisely defined in "Gemeine Irtheile" - it constituted there 12 grzywnas. ${ }^{65}$ According to the above-mentioned regulations of all the revisions of the Chełmno law, the basic wergild amounted to 24 grzywnas. Thus, formally the wergild in the early modern period remained on the same level as in the Middle Ages, which was not very high. It must be remembered that the law concerned mainly the judiciary system in cities. ${ }^{66}$ In judicial practice, different amounts of the wergild were administered, particularly in reference to the upper classes. In 1607 in Braniewo the sentence for the killing of a Jerzy Follert by a student (probably a Polish nobleman) amounted to 650 Polish florins. ${ }^{67}$ It is hard to say whether it was only the wergild, or whether it included also some additional public charges. What seems to prove that the latter was true is another case in Braniewo, which took place in 1635. The case concerned the killing in self-defence, and the perpetrator had to pay the sentence of 100 grzywnas for the benefit of the town, while the widow was to receive from him 30 grzywnas. ${ }^{68}$ The same happened in the case of Krzysztof Donajski, a nobleman from the district of Przezmark, who in 1614 was sentenced to pay 700 grzywnas to cover the costs and the compensation to the family of Paweł Prawda, whom he had killed two years before in a market in Zalew. The last case included the additional punishment - the so called act of humility, which consisted in the obligation of Krzysztof Donajski's kneeling down

${ }^{60}$ Rewizja nowomiejska, book V, art. CCXCI.25, p. 141.

${ }^{61}$ Ibid., book II, art. XXXIV.16, pp. 57-58.

${ }^{62}$ Rewizja lidzbarska, book III.33, p. 127.

${ }^{63}$ Ibid., book III.91, 94, pp. 154-155.

${ }^{64}$ F. Neumann, op. cit., p. 174.

${ }^{65}$ Die lauffende Urtel, pp. 20-21.

${ }^{66}$ A. SzorC, op.cit., p. 351; D. JANickA, op. cit., pp. 7-8, 134-135; J. Sondel, op. cit., p. 15, the evidence of which are extensive accounts about town councillors, the mayor, etc.

${ }^{67} \mathrm{~J}$ [akob] A[loys] Lilienthal, Die Rechtspflege in der Altstadt Braunsberg von der ältesten Zeit bis zur preußischen Besitznahme im Jahre 1772, Der neuen Preußischen Provinzial-Blätter ander Folge, Bd. 1: 1852, p. 24. In Braniewo the Lübeck law was in force.

${ }^{68}$ Ibid., s. 8; G. MATERN, op. cit., p. 34. 
at the tomb of the killed victim with a sword taken out in the presence of his relatives on three consecutive Sundays. The moment the crime was committed Donajski was drunk, like his victim. Despite this, the sentence issued by the local court in Zalew, though approved of by both parties, was recognized by the Supreme Court in Königsberg, which, upon the revision of 1615, sentenced Donajski for banishment from Prussia, the consequences of which was the fact that everybody could kill him without any punishment. ${ }^{69}$

As part of the wergld an inn-owner Engelien in 1638 was to give his inn in Belacken (now Gruszewka), the district of Kremitten (now Losowoje) along with all its facilities to the relatives of the killed victim from the family of the von der Diehle. As it was underlined in the settlement document, it also resulted from the fact that the inn was situated very close to the estate belonging to the von der Diehle family (Popelken, now Cholmy) and both parties wanted to avoid future mutual contacts. As the value of the inn was much higher than the value of the wergild the relatives of the victims were to give back to the inn-owner 1000 Polish florins in two installments. As a penance, Engelien was to pay 100 grzywnas for the benefit of the church in Kremitten and avoid contacts with the sons and relatives of the killed person. Having met the conditions, Engelien was allowed to "frei und sicher von ihnen zu Stege und Wege frei und ungefährdet sein."70

In the pre-Christian period and in the Middle Ages (in the Teutonic times) the value of the wergild depended on the "quality of the person" - their social status, social class, the position they held, their sex and age. ${ }^{71}$ In the Teutonic time upper classes were entitled to higher rates of the wergild (up to 60 grzywnas). In the legal acts, starting from "Gemeine Urtheile" down to the revisions of the Chełmno law there existed an equality of everybody before the punishment. ${ }^{72}$ However, it did not mean the equal value of the wergild. As we learn from the "Nowe Miasto revision" [Rewizja nowomiejska], its value should be estimated depending on the honour or social strata of the killed person. ${ }^{73}$ It is confirmed by other examples, which reflect the diversification of the punishment depending on the social position of the perpetrator. In the above-mentioned case from Braniewo, where the burgher was killed by the student - probably a nobleman of Polish origin, the punishment constituted only financial compensation of 650 Polish florins, despite the fact that the victim' father underlined it to the council that it was a case of utmost importance. ${ }^{74}$ In 1658 , also in Ermland [Warmia] a nobleman Johann von Schwaben was to pay

${ }^{69}$ G. A. von Mülverstedt, op. cit., pp. 410-411: "also da $\beta$ er aus dem frieden in den unfreiden gesetzer und sein leib und leben wie eines vogels in der Luft jedermann gemein und in diesem hertzokgthumb Preußen erlaubt sei ihn ohne alle Straffe vom Leben zum Todte zu bringen und wegen dessen niemand sich an Ihme verbrechen möge oder könne."

${ }^{70}$ Ibid., p. 402; [L.] von BACZKO, op. cit., pp. 358-359.

${ }^{71}$ P. TyszKa, op. cit., pp. 158-160; G. BiAŁUŃsKi, op. cit., pp. 19-20.

${ }^{72}$ D. JANICKA, op. cit., pp. 58-59.

${ }^{73}$ Rewizja nowomiejska, book II, art. XXXVII.19, p. 59.

${ }^{74}$ J. A. Lilienthal, op. cit., p. 24. 
200 grzywnas for killing a man from the lower class. ${ }^{75}$ The amount of the wergild to be paid was not determined by the sex of the people involved. ${ }^{76}$ Nevertheless, theoretically the minors were excluded from the punishment (formally the wergild was paid from their wealth by their legal guardian). ${ }^{77}$ In The General State Laws for the Prussian States higher punishments were guaranteed for injuring an official on duty and a person holding the function of a guardian in the princely forests. ${ }^{78}$

In the Duchy of Prussia the wergild disappeared from The General State Laws for the Prussian States of 1620. It so happened owing to the Roman law and the direct influence of Carolina (Constitutio Criminalis Carolina ${ }^{79}$ ), which recognized only public punishments and eliminated the institution of self-support and the punishment of composition..$^{80}$ However, in the judicial practice the wergild continued to be used, but, as was noticed by G. A. von Mülverstedt, from the turn of the $16^{\text {th }}$ and the $17^{\text {th }}$ centuries the courts were more inclined to give death sentences without the possibility of exchanging it for the wergild. ${ }^{81}$ In the literature of the subject matter the last case of the wergild took place for the killing of Georg Albrecht von der Diehle by the inn-owner Zachariasz Engelien in the Duchy of Prussia. The settlement was concluded between the heirs of the victim and the killer and his family in $1638 .{ }^{82}$ In Ermland [Warmia] the last cases of the wergild occurred in 1635 and $1658 .{ }^{83}$ In the meanwhile Ludwik von Baczko claimed that the wergild be paid for the unintentional killing in Königsberg in $1754 .{ }^{84}$ It took place probably owing to the fact that the courts used both The General State Laws for the Prussian

${ }^{75}$ A. Szorc, op. cit. p. 407.

${ }^{76}$ D. JANICKA, op. cit., p. 48.

${ }^{77}$ Rewizja nowomiejska, book V, art. CCCXV.49, pp. 146-147; Rewizja lidzbarska, book III.34, p. 128.

${ }^{78}$ W. LiTewsKi, op. cit., p. 142.

${ }^{79}$ Des allerdurchleuchtigsten großmechtigsten vnüberwindtlichsten Keyser Karls des fünfften: vnnd des heyligen Römischen Reichs peinlich gerichts ordnung auff den Reichsztägen zu Augspurgk vnd Regenspurgk inn jaren dreissig vnd zwey vnd dreisssig gehalten auffericht vnd beschlossen, Mainz 1533.

${ }^{80}$ Ibid., pp. 61-62; Michał PatKaniowski, Wina i kara. Elementy rzymskie i germańskie w prawie karnym statutów miast włoskich, Kraków 1939, pp. 7, 125-127.

${ }^{81}$ G. A. von MüLverstedt, op. cit., p. 398, the example of the von Bothmar brothers hanged for killing two peasants on the public road.

82 [L.] von BaczKo, op.cit., pp. 357-360; G. A. von Mülverstedt, op. cit., pp. 399-400, 411; J. A. Lilienthal, op.cit., p. 24; after the work by Ludwig von Baczko. The killing took place in 1631 at the court of Popelken, in the district of Kremitten, belonging to the victim. The perpetrator was sentenced to death, but the parties agreed on settlement upon the permission of the Polish king and the elector of Brandendurg. The written settlement was signed in 1638.

${ }^{83}$ G. Matern, op. cit., p. 34; A. Szorc, op.cit., p. 407.

84 [L.] von BACZKo, op. cit., pp. 360-361; G. A. von MüLVERstedt, op. cit., p. 400, stated that the name of wergild was used in the technical sense to refer to a fine ("private satisfaction in the case of death"). It does not seem to be correct since the fine "statt eines Wehrgeldes" of 20 thalers ( 24 grzywnas) was paid to the widow and her minor children, which corresponded to the value of the wergild; both killers had to pay some additional charges, e.g. for example for the surgeon, pro Ministeriali oraz pro publico bono. 
States and the Chełmno law, ${ }^{85}$ where the wergild was recognized as punishment. Besides, the analyzed examples allow us to assume that the wergild was permitted mostly among noblemen.

Let me now turn to the issue of the vendetta. It must be underlined that for the legislators of the time one of the reasons for punishing a manslayer was still retaliation ("so that [...] murder not be avenged"). ${ }^{86}$ However, it could be done only by the courts. The prohibition of the vendetta ("Befehden"), or even the publicly announced intention to execute it ("Absagung") appeared in the Torun revision of the Chełmno law (1594). ${ }^{87}$ Still, we have to reject the suggestion appearing in the literature that the bloody vendetta in Prussia disappeared in the $14^{\text {th }}$ century. ${ }^{88}$ It is true that in the legal regulations of the Chełmno law from the time of the Torun revision the vendetta was not mentioned. It may be explained by a legal gap in the Saxon-Magdeburg sources, on which the regulations were modelled. ${ }^{89}$ By no means does it mean that the vendetta did not exist anymore. The Torun revision stipulated that beheading be the punishment for the vendetta and its announcement (like in Carolina). Only settlement or penitence supported by the public withdrawal from the intention to execute the vendetta allowed the court to apply a softer punishment such as whipping or banishment ("Verweisung"). ${ }^{90}$ In The General State Laws for the Prussian States the vendetta is prohibited under the threat of death penalty by beheading with a sword. ${ }^{91}$ Like in the Torun revision, letters in which the intention of the vendetta was expressed ("Fehdes Brieffe") or even the fact of helping to write such a letter were to be punished as well. ${ }^{92}$

${ }^{85}$ [L.] von BACZKo, op. cit., pp. 361-364 seems to put forward a similar suggestion. Although in the introduction to the General State Laws for the Prussian States it was forbidden to quote regulations which were not in accordance with the General State Laws. The regulations provided by the Chełmno law were to be lifted if they were not in accordance with the General State Laws. However, in practice, in some exceptional situations the Chełmno law was applied as the traditional law, comp. Stanisław SALmonowicz, Z dziejów wschodniopruskich kodyfikacji prowincjonalnych (XVII-XIX w.). Przyczynek do losów prawa chetmińskiego w państwie brandenbursko-pruskim, [in:] Studia Culmensia Historico-Juridica czyli księga pamiątkowa 750-lecia prawa chełmińskiego, ed. Zbigniew ZDrójKowSKI, Torun 1988 , pp. 288, 298, 322-323. In the $17^{\text {th }}$ and $18^{\text {th }}$ century the code of "Gemeine Urtheile" was very popular.

${ }^{86}$ Rewizja lidzbarska, book II, art. 61, p. 111.

${ }^{87}$ Comp. D. JANickA, op. cit., p. 91.

${ }^{88}$ Владимир Терентьевич Пашуто, Помезания. «Помезанская правда» как исторический источник изучения общественного и политического строя Помезании XIII-XIV вв., Москва 1955, p. 96.

${ }^{89}$ D. JANICKA, op. cit., p. 91.

${ }^{90}$ Ius Culmense ex ultima revisione, V2, 15, 1, 4, 5, p. 250; D. JANICKA, op. cit., p. 92, here the punishment of whipping and banshmeny together.

${ }^{91}$ W. Litewski, op. cit., pp. 61-62, 98; Churfürstlich Brandenburgisches revidirtes Landrecht des Herzogthumbs Preussen, Bd. VI, tit. V, art. I, $\$$ VI-VII, pp. 895-896.

${ }_{92}$ Churfürstlich Brandenburgisches revidirtes Landrecht des Herzogthumbs Preussen, Bd. VI, tit. V, art. I, § VII-IX, pp. 896-897. 
And what did it look like in practice? There existed a regulation in the Willkür of Allenstein [Polish: Olsztyn] of 1568 - the Olsztyn collection of legal acts - about the prohibition of applying personal revenge instead of holding a proper trial in court, which is the evidence of there being such a custom in towns. The punishment was banishment from the town..$^{93}$ The existence of the vendetta is confirmed by the case of Krzysztof Donajski, who, having killed Paweł Prawda, fled abroad and joined the army in the Netherlands for fear of the vendetta from the victim's relatives. ${ }^{94}$ The same happened with Jan Prawda (from the same family as Pawel Prawda), who, having committed a homicide, escaped to Hungary and joined the army fighting against Turks. Still, he endeavored to win the elector's mercy and his consent for the settlement and the payment of the wergild. ${ }^{95}$ Another case was Christoph von Konobelsdorf, a nobleman from the district of Bartschin [Polish: Barcin], who in 1587 killed in a duel another nobleman from the family of von Bochsen. He had to flee to Prussia and hide in the house of his relatives in Lausitz [Polish: Łużyce] ${ }^{96}$ lest the victim's relatives use the vendetta against him. Thus, it must be underlined that although the early modern laws in Prussia formally excluded the use of the vendetta, in practice it was still applied. The alternative for this norm was the permission of both parties for the settlement, which appeared in all the collections of legal acts of the epoch. ${ }^{97}$ In this context we should look at the escape of the perpetrators abroad, which not only save their lives, but also made it easier to work out the settlement. ${ }^{98}$ This is the custom we know from Poland. It was used only in the case of noblemen and was referred to as the vendetta ("laudum," "vulgariter," "wrozba," “absentatio," "exilium"). ${ }^{99}$

At this stage of the research it is hard to draw clear-cut conclusions, but it seems that customarily the vendetta in the early modern period continued to exist - at least among noblemen. Its use was reduced by the regulations sentencing

${ }^{93}$ Danuta Bogdan, Wilkierz miasta Olsztyna z 19 sierpnia 1568 roku, [in:] Olsztyn w dokumentach. Wybór źródeł do historii miasta 1353-1949, ed. eadem, Olsztyn 2015, p. 33. The regulation is general and refers to retaliation, but we should assume that it did not exclude retaliations for killing and injuries.

${ }^{94}$ G. A. von Mülverstedt, op. cit., p. 410.

${ }^{95}$ Ibid., pp. 411-412.

${ }^{96}$ Ibid., p. 397.

${ }^{97}$ The most recent codes excluded the possibility of settlement, but the prohibition seems not to have been obligatory; it seems that only settlements concluded beyond the knowledge and permission of the court and settlements concluded with aim of avoiding a public sentence (Churfürstlich Brandenburgisches revidirtes Landrecht des Herzogthumbs Preussen, Bd. VI, tit. V, art. I, $₫$ VIII, pp. 896-897). Nevertheless, the conclusion of the settlement was not binding for the judge and left further proceedings and trial for him to decide (Ius Culmense ex ultima revisione, V1, 4, 4, p. 212).

${ }^{98}$ G. A. von Mülverstedt, op. cit., pp. 397-398.

${ }^{99}$ More about retaliation [wróżda] see Stanisław KutrzebA, Mężobójstwo w prawie polskiem XIV i XV wieku, Rozprawy Akademii Umiejętności. Wydział Historyczno-Filozoficzny, vol. 25, Kraków 1907, pp. 155-157; Adolf PAwiński, O pojednaniu w zabójstwie według prawa polskiego, Warszawa 1884 , pp. $50-59$. 
executors of the vendetta to death, and by the regulations maintaining the possibility of settlement. Unlike in the Middle Ages, the vendetta was limited to the perpetrator only, and not to their whole family.

To sum up, it may be stated that according to sources the wergild in Prussia was applied until the mid- $18^{\text {th }}$ century, despite the fact that the general rule in such cases was death sentence. The wergild was a punishment traditionally recognized by the Chełmno law and its subsequent revision, which explains its longevity. At the beginning of the early modern period the wergild was allowed only in the case of homicide committed in self-defence or unintentional killing. The person guilty of intentional killing was punished according to the law of retaliation. Applying the principle of retaliation excluded collective responsibility. Next, the wergild was prohibited to be used by courts and the principle of retaliation was rejected. The next step reducing the use of the wergild was applying it only in reference to unintentional or accidental killings and in self-defence.

The sentence about the wergild was issued by the court, upon the agreement for the settlement between the parties. The wergild was permitted mainly among noblemen, which overlapped with contemporary Polish law. ${ }^{100}$ The circle of people entitled to collect the wergild was reduced to the closest agnate. The responsibility to pay the wergild was limited to the perpetrator. Apart from this, the wergild was not shared with the supreme authority, the judge being the only person to receive a fee called mulkta. The value of the wergild depended on the position and the social class of the victim. The wergild constituted a kind of financial unit to indicate the sums of fines and compensation damages. Apart from the compensation, it also made up for physical injuries and a detriment to honour. The latter was also associated with additional punishments such as the act of submission.

The custom of the bloody retaliation (vendetta) survived until the mid-17 $7^{\text {th }}$ century, despite new legal acts which prohibited it under the threat of death sentence. Still, the settlement was an option. The vendetta was limited only to the perpetrator of the crime.

(transl. by Agnieszka Chabros)

Received 24 $4^{\text {th }}$ March 2016

Received in revised form $15^{\text {th }}$ June 2016

Accepted $26^{\text {th }}$ June 2016

Prof. dr hab. Grzegorz Białuński

Institute of History and International Relations

University of Warmia and Mazury in Olsztyn

e-mail: grzegorz.bialunski@uwm.edu.pl

${ }^{100}$ D. JaniCKA, op. cit., s. 96; S. KutrzebA, op. cit., pp. 148, 178. 


\section{SCHON WILLKÜR ODER NOCH RECHT? ÜBER DAS WERGELD UND DIE BLUTRACHE IM HERZOGLICHEN UND KÖNIGLICHEN PREUSSEN IN DER NEUZEIT}

\section{Zusammenfassung}

Schlüsselwörter: neuzeitliches Strafrecht, Kulmer Recht, preußische Landrechte, ermländische Justiz in der Neuzeit, Blutrache

Das Wergeld als Geldstrafe für Mord hat sich in Preußen nachweislich bis zur Mitte des 18. Jahrhunderts erhalten, obwohl der allgemeine Grundsatz in solchen Fällen bereits die Verurteilung der Täter zum Tod geworden war. Dass sich das Wergeld so lange halten konnte, ist hauptsächlich damit zu erklären, dass die Gerichte das Kulmer Recht anwandten, in dem das Wergeld eine von der Tradition sanktionierte Strafe war, aber auch damit, dass dieses Recht immer wieder neu zusammengestellt wurde. An der Schwelle zur Neuzeit konnte ein Wergeld als Strafe nur im Fall von Verbrechen in Notwehr oder aus Zufall ausgesprochen werden, während bei bewusst begangenen Verbrechen der Schuldige nach dem Talionsprinzip zur Verantwortung zu ziehen war. Die Anwendung des Talionsprinzips schloss allerdings die Zuerkennung einer Gruppenverantwortung aus. Später wurden dann die Anwendung des Wergelds außerhalb eines Gerichts ausgeschlossen und das Talionsprinzip verworfen. Weitere Schritte, die die Bedeutung des Wergelds begrenzten, waren seine Anwendung nur noch im Fall von unbewusstem und zufälligem Totschlag sowie die Befreiung von dieser Strafe im Fall von Totschlag aus Notwehr.

Ein Urteil über die Zuerkennung eines Wergelds wurde von einem Gericht gefällt, das dies aber bei Einverständnis der Parteien zu einer gütlichen Einigung anderen Schiedskörperschaften überließ. Die Zahlung eines Wergelds wurde vor allem im Fall von Adligen zugelassen, was dem zeitgenössischen polnischen Recht entsprach. Der Kreis der Personen, die zum Empfang eines Wergelds berechtigt waren, wurde auf den nächsten Verwandten in männlicher Linie begrenzt, entsprechend der Nähe des Verwandtschaftsgrads, die Zahlung einer Geldstrafe für Totschlag nur auf den Schuldigen selbst. Außerdem wurde das Wergeld nicht mehr mit der Obrigkeit geteilt, nur der Richter erhielt unabhängig von ihm eine Gebühr, die mulcta genannt wurde. Die Höhe des zu zahlenden Wergelds wurde nach der Würde (dem Amt) oder dem Stand des Getöteten geschätzt. Das Wergeld war außerdem eine Art von Berechnungseinheit für die Festsetzung der Höhe von Geldstrafen und Entschädigungen. Neben der Genugtuung in Form einer Entschädigung in Geld war es auch eine Wiedergutmachung für physischen Schaden und auch für Beeinträchtigung der Ehre. Mit Letzterem waren zusätzliche Strafen verbunden, zum Beispiel ein Akt der Demütigung.

Bis etwa zur Mitte des 17. Jahrhunderts gab es weiterhin die Sitte der Blutrache, zumindest unter dem Adel. Sie wurde zwar von neuen rechtlichen Regelungen ausgeschlossen, die die Todesstrafe androhten, aber noch immer war die Möglichkeit der Einigung der Parteien eine Alternative. Die Rache wurde lediglich auf den Verursacher des Mords eingeschränkt. 
LAWLESS OR STILL LAWFUL?

ABOUT WERGILD (MAN-PRICE) AND VENDETTA IN THE DUCHY OF PRUSSIA AND ROYAL PRUSSIA IN THE EARLY MODERN TIMES

\section{Summary}

Key words: early modern criminal law, Chełmo law, the General State Laws for the Prussian States, the judicial system of early modern Warmia (Ermland), bloody retaliation

The wergild as a financial punishment for husband killing survived in Prussia until the mid- $18^{\text {th }}$ century, but the general rule was that the perpetrators of husband killing were sentenced to death. The reason why the wergild survived for such a long time in Prussia was the fact that courts applied the Chelmno law, according to which the wergild was recognized by tradition and also found in subsequent registers of the Chełmno law. At the beginning of the early modern period the wergild could apply only in case of assassinations committed in self-defense or by accident; deliberate crimes were subject to the law of retaliation. Yet, the law of retaliation could not be applied in relation to groups. With time the wergild could not be used out of court and the law of retaliation was abolished. The next step restricting the use of the wergild was the fact that it was to be applied in case of unintentional or accidental homicides; moreover, in case of killing in self-defence the perpetrator was exempt from the wergild.

It was the court that passed a sentence of the wergild, but in cases of reconciliation the sentence was passed by other arbitration bodies. The wergild was allowed mainly among noblemen, which was in accordance with the Polish law of the time. The circle of people entitled to the wergild was reduced to the closest agnate, while in case of husband killing it applied only to the perpetrator. The wergild was no longer shared with the authorities; it was only the judge who received the fee referred to as multa. The value of the wergild was determined by the rank of the office held by the assassinated person. Moreover, the wergild constituted a kind of financial unit used to establish the value of fines and compensatory damages. Apart from the compensation in the form of financial gratification, the wergild constituted the indemnification for physical injury or damage to honour. The latter could also entail some additional punishment e.g. the act of submission.

Until the mid- $17^{\text {th }}$ century the tradition of bloody retaliation (vendetta) was practiced at least among the nobility. It was illegal and punished by death sentence. Its alternative continued to be the possibility of settlement. The retaliation was limited only to the perpetrator of the homicide. 